\title{
Copy Number Alterations and Methylation in Ewing's Sarcoma
}

\author{
Mona S. Jahromi, ${ }^{1}$ Kevin B. Jones, ${ }^{2,3}$ and Joshua D. Schiffman ${ }^{1,3,4}$ \\ ${ }^{1}$ Department of Oncological Sciences, Huntsman Cancer Institute, University of Utah School of Medicine, 2000 Circle of Hope, \\ Salt Lake City, UT 84112, USA \\ ${ }^{2}$ Department of Orthopaedics, Huntsman Cancer Institute, University of Utah School of Medicine, 2000 Circle of Hope, \\ Salt Lake City, UT 84112, USA \\ ${ }^{3}$ Center for Children's Cancer Research (C3R), Huntsman Cancer Institute, University of Utah School of Medicine, \\ 2000 Circle of Hope, Salt Lake City, UT 84112, USA \\ ${ }^{4}$ Division of Pediatric Hematology/Oncology, Huntsman Cancer Institute, University of Utah School of Medicine, \\ 2000 Circle of Hope, Salt Lake City, UT 84112, USA
}

Correspondence should be addressed to Joshua D. Schiffman, joshua.schiffman@hci.utah.edu

Received 15 September 2010; Accepted 3 January 2011

Academic Editor: Peter Houghton

Copyright ( $) 2011$ Mona S. Jahromi et al. This is an open access article distributed under the Creative Commons Attribution License, which permits unrestricted use, distribution, and reproduction in any medium, provided the original work is properly cited.

\begin{abstract}
Ewing's sarcoma is the second most common bone malignancy affecting children and young adults. The prognosis is especially poor in metastatic or relapsed disease. The cell of origin remains elusive, but the EWS-FLI1 fusion oncoprotein is present in the majority of cases. The understanding of the molecular basis of Ewing's sarcoma continues to progress slowly. EWS-FLI1 affects gene expression, but other factors must also be at work such as mutations, gene copy number alterations, and promoter methylation. This paper explores in depth two molecular aspects of Ewing's sarcoma: copy number alterations (CNAs) and methylation. While CNAs consistently have been reported in Ewing's sarcoma, their clinical significance has been variable, most likely due to small sample size and tumor heterogeneity. Methylation is thought to be important in oncogenesis and balanced karyotype cancers such as Ewing's, yet it has received only minimal attention in prior studies. Future CNA and methylation studies will help to understand the molecular basis of this disease.
\end{abstract}

\section{Introduction}

Ewing's sarcoma is a highly malignant tumor of children and young adults. The molecular mechanisms that underlie Ewing's sarcoma development are beginning to be understood, but the genetic risk factors leading to disease susceptibility remain largely unknown. Ewing's sarcoma is the second most common pediatric bone cancer after osteosarcoma, with $30-60 \%$ survival depending on tumor site and metastases at diagnosis $[1,2]$. When patients with Ewing's sarcoma relapse, it is usually fatal: less than $20 \%$ survive [3-5]. Beyond incremental improvements in cytotoxic chemotherapy regimens, there have been no major treatment advances in the last 20 years $[6,7]$. Clinical features are the only markers that have been found to correlate reliably with the outcome in Ewing's sarcoma, but no risk-adapted therapy has proven successful; worse prognosis in Ewing's is predicted by metastatic disease measured by imaging and bone marrow examination, larger tumor volume, and primary tumors in the pelvis [8]. While osteosarcoma is thought to originate from bone cell progenitors [9], the cell of origin of Ewing's sarcoma is less clear with some evidence suggesting that tumors arise from a mesenchymal stem or progenitor cells [10-12]. Other researchers in the field believe instead that Ewing's sarcoma develops from a neuroectodermal origin [13-17]. The lack of a known cell of origin contributes to the difficulty in understanding exactly how Ewing's sarcoma develops or even how to design laboratory experiments to study tumorigenesis.

Nearly every case of Ewing's sarcoma contains a translocation involving the EWSR1 gene on chromosome 22. The most common rearrangement is $\mathrm{t}(11 ; 22)(\mathrm{q} 24 ; \mathrm{q} 12)$, which generates the EWS-FLI1 fusion oncogene, found in $\sim 85 \%$ of Ewing's cases [18-21]. The translocation $\mathrm{t}(21 ; 22)$ (q22;q12) 
is found in another $10 \%$ of cases $[21,22]$ and the remainder of EWS translocations utilize a variety of fusion partners from the ETS family of transcription factors $[19,20]$. All of the Ewing's sarcoma fusion proteins contain a strong transcriptional activation domain fused to a DNA-binding domain and function as aberrant transcription factors that dysregulate a number of target genes and contribute to oncogenic transformation [18-21,23-30]. The EWSFLI1 translocation is the best understood and most wellcharacterized molecular aspect of Ewing's sarcoma. This translocation (or one of the alternates) is thought to be necessary but not sufficient to cause disease [31].

In addition to translocations, neoplastic development in cancer depends on other acquired molecular changes. Such changes in tumor biology include copy number alterations (CNAs), such as genomic deletions or amplifications, and methylation abnormalities. As newer technology has become available in recent years, we have learned more about CNAs and methylation in Ewing's sarcoma and possible associations with outcome, disease classification, and tumorigenesis. These molecular investigations have been limited by the rarity of Ewing's sarcoma and the small tumor samples obtained at initial diagnostic biopsy available for analysis. Nevertheless, many overlapping regions of CNAs and methylation have been described; their underlying significance is not always clear. Further exploration as to how these changes affect the outcome and their prevalence is essential to the development of future treatment options. In this paper, we describe the reported CNAs and methylation changes associated with Ewing's sarcoma and any known clinical correlations with these molecular findings.

\section{Materials and Methods}

Literature searches for articles containing "Ewing's sarcoma copy number" and "Ewing's sarcoma methylation" were performed via the PUBMED database. Results consisted of 15 separate journal articles for copy number and 14 for methylation. Twelve relevant publications were selected for copy number and their references explored and included when appropriate. Nine relevant promoter methylation articles were selected and their references explored.

\section{Results and Discussion}

3.1. Ewing's Sarcoma and Copy Number Alterations (CNAs). Specific CNAs predict prognosis in several cancers and have been introduced as part of clinical risk stratification for colorectal and breast cancer, neuroblastoma, and brain tumors [32-35]. Despite intense investigation of Ewing's sarcoma biology, very few molecular markers have been discovered for routine clinical use in this disease. In contrast, active risk stratification based on molecular cytogenetics has increased the cure rate for childhood acute lymphoblastic leukemia (ALL) from less than $50 \%$ to over $85 \%$ in only a few decades [36]. Moreover, the use of high-resolution single nucleotide polymporphism (SNP) technology has been used to identify recurring CNAs in childhood leukemia [37-42] including relapsed cohorts [43, 44]. The study of
CNAs in cancer also helps to better classify and understand the development of disease. For example, CDKN2A homozygous deletions in pediatric gliomas were recently found to significantly associate with specific $\mathrm{BRAF}^{\mathrm{V} 600 \mathrm{E}}$ mutations, helping to define a new subset of tumors [45]; the same deletion and mutation were also shown to work together to promote glioma formation in mice, validating the cooperation between CNAs and mutations [46].

New genomic technology has proven effective in determining copy number changes in a variety of tissue types. Previously, DNA extracted from paraffin has been too degraded to yield reliable data for analysis, but a new molecular inversion probe assay (OncoScan, Affymetrix, Santa Clara, CA) has been used successfully to identify copy number changes in formalin-fixed paraffin-embedded (FFPE) samples [65]. The ability to now interrogate FFPE samples allows the analysis of archival tissues and increases sample sizes for future Ewing's sarcoma studies. Copy number assessment in combination with clinical data could be used to identify CNAs in archival tissue and determine their link to the outcome in Ewing's sarcoma. Moving forward, candidate loci could be further studied in vitro or in pre-clinical animal models to determine their contribution to drug resistance and tumor progression.

A large number of novel and recurrent secondary abnormalities in Ewing's tumors relating to copy number already have been discovered (see summary Table 1). The vast majority of copy number studies thus far in Ewing's sarcoma have been performed with comparative genomic hybridization $(\mathrm{CGH})$ technology on either cell lines or primary samples. The most commonly reported CNAs in Ewing's sarcoma are trisomies of chromosomes 8 and 12 followed by the gain of 1q [47-49, 51-57, 66, 67]. Trisomy 8 is of particular interest as it occurs consistently and often in high frequency, being reported in $\geq 50 \%$ of cases in Ewing's sarcoma $[47,56,57]$. The oncogene, MYC, is thought to be a possible candidate driver of trisomy 8 as it was shown to bestow a selective advantage through nonfocal amplification when studied in undifferentiated soft tissue sarcomas [67]. In contrast to these findings, many studies have not found a statically significant link to survival outcomes in Ewing's sarcoma and trisomy $8[47,51,54,56]$. Despite the lack of statistical significance, some evidence does suggest a link between trisomy 8 and worse outcome or worse overall survival. Values for 5 -year distant disease-free survival $(P=$ .16) and overall survival $(P=.39)$ were not statistically significant, but the percentage of trisomy 8 was greater in both survival categories implicating a possible, though not statistically relevant, trend [54]. Focal amplifications in both the long and short arms of chromosome 8 (opposed to the entire trisomy) have been associated with clinical outcomes in Ewing's sarcoma. Specifically, Ozaki et al. reported that $8 p$ amplifications occurred at higher frequency in relapsed cases compared to primary tumors $(P=.04)$ [48]. They also found that combinations of CNAs, including $8 \mathrm{q}$ amplification in conjunction with chromosome 20 amplifications, were significant for worse cumulative overall survival rates $(P=$ .0065) [48]. Savola et al. have proposed WDR67 (8q24.13) and GSDMD1 (8q24.3) as interesting candidate genes for 
TABLE 1: Summary of copy number alternations (CNAs) in Ewing's Sarcoma (tumor, cell line, and xenograft) in published literature.

\begin{tabular}{|c|c|c|c|c|c|c|}
\hline Deletion & Gain & $\begin{array}{c}\text { Ewing's } \\
\text { sample type }\end{array}$ & Frequency (\%) & Technology & Study & Clinical significance \\
\hline $1 \mathrm{p}$ & & ESFT & $17 / 184(9 \%)$ & $\begin{array}{l}\text { Karyotyping } \\
\text { and CGH }\end{array}$ & $\begin{array}{l}\text { Hattinger et al. [47]; } \\
\text { Ozaki et al. [48] }\end{array}$ & \\
\hline $1 \mathrm{p} 36$ & & ESFT & $5 / 88(6 \%)$ & $\begin{array}{l}\text { Karyotyping } \\
\text { (G-Band) }\end{array}$ & Roberts et al. [49] & \\
\hline \multirow[t]{6}{*}{$1 \mathrm{p} 36.32-\mathrm{p} 36.11$} & & ESFT & $2 / 9(22 \%)$ & $\begin{array}{l}\text { SNP Microarray } \\
\text { (Affy } 100 \mathrm{~K} \text { ) }\end{array}$ & Neale et al. [50] & \\
\hline & $1 \mathrm{q}$ & ESFT & $77 / 396(19 \%)$ & $\begin{array}{l}\text { Karyotyping } \\
\text { and CGH }\end{array}$ & $\begin{array}{l}\text { Armengol et al. [51]; } \\
\text { Brisset et al. [52]; } \\
\text { Hattinger et al. [47]; } \\
\text { Ozaki et al. [48]; } \\
\text { Roberts et al. [49]; } \\
\text { Savola et al. [53]; } \\
\text { Tarkkanen et al. [54] }\end{array}$ & $\begin{array}{l}\text { (i) Adverse event free survival } \\
\text { (ii) Adverse overall survival } \\
\text { (iii) Age at diagnosis } \geq 15 \text { years } \\
\text { (iv) Metastatic (trend) }\end{array}$ \\
\hline & & Cell line & $5 / 8(63 \%)$ & CGH & Shing et al. [55] & \\
\hline & $1 q 21-q 22$ & ESFT & $5 / 28(18 \%)$ & $\mathrm{CGH}$ & Tarkkanen et al. [54] & $\begin{array}{l}\text { (i) Adverse overall survival (trend) } \\
\text { (ii) Adverse 5-year distant } \\
\text { disease-free survival (trend) }\end{array}$ \\
\hline & 2 & ESFT & $38 / 262(15 \%)$ & $\begin{array}{l}\text { Karyotyping } \\
\text { and } \mathrm{CGH}\end{array}$ & $\begin{array}{l}\text { Brisset et al. [52]; } \\
\text { Hattinger et al. [47]; } \\
\text { Roberts et al. [49], } \\
\text { Savola et al. [53] }\end{array}$ & (i) Localized disease \\
\hline & $2 \mathrm{q}$ & ESFT & $12 / 62(19 \%)$ & $\mathrm{CGH}$ & Ozaki et al. [48] & (i) Adverse overall survival \\
\hline \multirow[t]{7}{*}{$3 p$} & & Cell line & $3 / 8(38 \%)$ & $\mathrm{CGH}$ & Shing et al. [55] & \\
\hline & $4 \mathrm{p}$ & ESFT & $10 / 105(10 \%)$ & $\mathrm{CGH}$ & $\begin{array}{l}\text { Brisset et al. [52]; } \\
\text { Ozaki et al. [48] }\end{array}$ & (i) Relapse \\
\hline & 5 & ESFT & $28 / 231(12 \%)$ & $\begin{array}{l}\text { Karyotyping } \\
\text { and } \mathrm{CGH}\end{array}$ & $\begin{array}{l}\text { Brisset et al. [52]; } \\
\text { Hattinger et al. [47]; } \\
\text { Roberts et al. [49] }\end{array}$ & \\
\hline & $5 p$ & ESFT & $5 / 25(20 \%)$ & $\mathrm{CGH}$ & Ferreira et al. [56] & \\
\hline & 6 p21.1 pter & ESFT & $3 / 28(11 \%)$ & $\mathrm{CGH}$ & Tarkkanen et al. [54] & $\begin{array}{l}\text { (i) Adverse overall survival } \\
\text { (ii) Adverse 5-year distant } \\
\text { disease-free survival }\end{array}$ \\
\hline & 7 & ESFT & $26 / 216(12 \%)$ & $\begin{array}{l}\text { Karyotyping } \\
\text { and CGH }\end{array}$ & $\begin{array}{l}\text { Hattinger et al. [47]; } \\
\text { Roberts et al. [49]; } \\
\text { Tarkkanen et al. [54] }\end{array}$ & \\
\hline & $7 \mathrm{p} 21.1-\mathrm{p} 11.2$ & ESFT & $2 / 9(22 \%)$ & $\begin{array}{l}\text { SNP Microarray } \\
\text { (Affy } 100 \mathrm{~K} \text { ) }\end{array}$ & Neale et al. [50] & \\
\hline \multirow[t]{8}{*}{$7 \mathrm{q}($ partial $)$} & & ESFT & $6 / 25(25 \%)$ & $\mathrm{CGH}$ & Ferreira et al. [56] & \\
\hline & $7 \mathrm{q}$ & ESFT & $5 / 28(18 \%)$ & $\mathrm{CGH}$ & Tarkkanen et al. [54] & \\
\hline & 8 & ESFT & $197 / 413(48 \%)$ & $\begin{array}{l}\text { Karyotyping, } \\
\text { CGH and FISH }\end{array}$ & $\begin{array}{l}\text { Armengol et al. [51]; } \\
\text { Brisset et al. [52]; } \\
\text { Ferreira et al. [56]; } \\
\text { Hattinger et al. [47]; } \\
\text { Maurici et al. [57]; } \\
\text { Ozaki et al. [48]; } \\
\text { Savola et al. [53]; } \\
\text { Tarkkanen et al. [54]; } \\
\text { Zielenska et al. [58] }\end{array}$ & $\begin{array}{l}\text { (i) Local recurrences (trend) } \\
\text { (ii) Relapse (trend) } \\
\text { (iii) Adverse overall survival (trend) } \\
\text { (iv) Adverse 5-year distant } \\
\text { disease-free survival (trend) }\end{array}$ \\
\hline & & Cell line & $8 / 8(100 \%)$ & $\mathrm{CGH}$ & Shing et al. [55] & \\
\hline & $8 p$ & ESFT & $30 / 62(48 \%)$ & CGH & Ozaki et al. [48] & (i) Relapse \\
\hline & $8 \mathrm{q}$ & ESFT & $32 / 62(52 \%)$ & CGH & Ozaki et al. [48] & \\
\hline & $8 \mathrm{q} 11.21-\mathrm{q} 22.3$ & ESFT & $6 / 9(67 \%)$ & $\begin{array}{l}\text { SNP Microarray } \\
\text { (Affy } 100 \mathrm{~K})\end{array}$ & Neale et al. [50] & \\
\hline & $8 \mathrm{q} 24.11-\mathrm{q} 24.21$ & ESFT & $7 / 9(78 \%)$ & $\begin{array}{l}\text { SNP Microarray } \\
\text { (Affy } 100 \mathrm{~K} \text { ) }\end{array}$ & Neale et al. [50] & \\
\hline
\end{tabular}


Table 1: Continued.

\begin{tabular}{|c|c|c|c|c|c|c|}
\hline Deletion & Gain & $\begin{array}{c}\text { Ewing's sample } \\
\text { type }\end{array}$ & Frequency (\%) & Technology & Study & Clinical significance \\
\hline $9 p$ & & ESFT & $7 / 31(23 \%)$ & $\mathrm{CGH}$ & Savola et al. [53] & \\
\hline $9 \mathrm{p} 21$ & & ESFT & $50 / 291(17 \%)$ & $\begin{array}{l}\text { Karyotyping, } \\
\text { CGH, FISH, } \\
\text { Southern Blot, } \\
\text { SNP Microarray } \\
\text { (Affy } 100 \mathrm{~K} \text { ), } \\
\text { and MLPA }\end{array}$ & $\begin{array}{l}\text { Brownhill et al. [59]; } \\
\text { Huang et al. [60]; } \\
\text { Kovar et al. [61]; } \\
\text { Neale et al. [50]; } \\
\text { Roberts et al. [49]; } \\
\text { Savola et al. [62]; } \\
\text { Wei et al. [63] }\end{array}$ & $\begin{array}{l}\text { (i) Adverse event free survival (trend) } \\
\text { (ii) Adverse overall survival } \\
\text { (iii) Axial } \\
\text { (iv) progressive disease (trend) } \\
\text { (v) Poor chemoresponse }\end{array}$ \\
\hline $9 \mathrm{p} 21$ & & Cell line & $24 / 43(56 \%)$ & $\begin{array}{l}\text { CGH (Agilent } \\
44 \mathrm{~K} \text { and } 244 \mathrm{~K} \text { ), } \\
\text { Taqman } \\
\text { qRT-PCR, FISH, } \\
\text { Southern Blot } \\
\text { and MLPA }\end{array}$ & $\begin{array}{l}\text { Brownhill et al. [59]; } \\
\text { Kovar et al. [61]; } \\
\text { Savola et al. [62] }\end{array}$ & \\
\hline $9 \mathrm{p} 21.3$ & & Xenotransplant & $4 / 12(33 \%)$ & dPCR, FISH & $\begin{array}{l}\text { López-Guerrero et al. } \\
{[64]}\end{array}$ & \\
\hline \multirow[t]{10}{*}{10} & & ESFT & $12 / 87(14 \%)$ & $\mathrm{CGH}$ & $\begin{array}{l}\text { Ferreira et al. [56]; } \\
\text { Ozaki et al. [48] }\end{array}$ & \\
\hline & $11 \mathrm{p}$ & ESFT & $2 / 62(3 \%)$ & & Ozaki et al. [48] & (i) Relapse \\
\hline & $11 \mathrm{q}$ & ESFT & $2 / 62(3 \%)$ & & Ozaki et al. [48] & (i) Relapse \\
\hline & 12 & ESFT & $104 / 434(24 \%)$ & $\begin{array}{l}\text { Karyotyping, } \\
\text { CGH and FISH }\end{array}$ & $\begin{array}{l}\text { Armengol et al. [51]; } \\
\text { Brisset et al [52]; } \\
\text { Ferreira et al. [56]; } \\
\text { Hattinger et al. [47]; } \\
\text { Maurici et al. [57]; } \\
\text { Roberts et al. [49]; } \\
\text { Savola et al. [53]; } \\
\text { Tarkkanen et al. [54]; } \\
\text { Zielenska et al. [58] }\end{array}$ & $\begin{array}{l}\text { (i) Adverse event free survival } \\
\text { (ii) Adverse overall survival } \\
\text { (iii) Relapse (trend) }\end{array}$ \\
\hline & $12 p$ & ESFT & $12 / 62(19 \%)$ & $\mathrm{CGH}$ & Ozaki et al. [48] & (i) Adverse overall survival \\
\hline & $12 \mathrm{q}$ & $\begin{array}{l}\text { ESFT } \\
\text { Cell line }\end{array}$ & $\begin{array}{c}11 / 62(18 \%) \\
6 / 8(75 \%)\end{array}$ & $\begin{array}{l}\mathrm{CGH} \\
\mathrm{CGH}\end{array}$ & $\begin{array}{l}\text { Ozaki et al. [48] } \\
\text { Shing et al. [55] }\end{array}$ & \multirow[t]{2}{*}{ (i) Adverse overall survival } \\
\hline & 12q14.1-q15 & ESFT & $2 / 9(22 \%)$ & $\begin{array}{l}\text { SNP Microarray } \\
\text { (Affy } 100 \mathrm{~K})\end{array}$ & Neale et al. [50] & \\
\hline & 14 & ESFT & $11 / 143(8 \%)$ & $\begin{array}{l}\text { Karyotyping } \\
\text { and CGH }\end{array}$ & $\begin{array}{l}\text { Brisset et al. [52]; } \\
\text { Hattinger et al. [47] }\end{array}$ & \multirow[b]{5}{*}{$\begin{array}{l}\text { (i) Adverse overall survival } \\
\text { (ii) Age at diagnosis } \geq 15 \text { years } \\
\text { (iii) Disseminated disease at diagnosis }\end{array}$} \\
\hline & $14 \mathrm{q} 11.2$ & ESFT & $2 / 9(22 \%)$ & $\begin{array}{l}\text { SNP Microarray } \\
\text { (Affy } 100 \mathrm{~K} \text { ) }\end{array}$ & Neale et al. [50] & \\
\hline & 15 & ESFT & $4 / 43(9 \%)$ & $\mathrm{CGH}$ & Brisset et al. [52] & \\
\hline & $16 \mathrm{p}$ & ESFT & $2 / 28(7 \%)$ & $\mathrm{CGH}$ & Tarkkanen et al. [54] & \\
\hline $16 \mathrm{q}$ & & ESFT & $69 / 396(17 \%)$ & $\begin{array}{l}\text { Karyotyping } \\
\text { and CGH }\end{array}$ & $\begin{array}{l}\text { Brisset et al. [52]; } \\
\text { Ferreira et al. [56]; } \\
\text { Hattinger et al. [47]; } \\
\text { Ozaki et al. [48]; } \\
\text { Roberts et al. [49]; } \\
\text { Savola et al. [53]; } \\
\text { Tarkkanen et al. [54] }\end{array}$ & \\
\hline $16 \mathrm{q}$ & & Cell line & $5 / 8(63 \%)$ & $\mathrm{CGH}$ & Shing et al. [55] & \\
\hline $16 q 22.3$ & & ESFT & $5 / 9(56 \%)$ & $\begin{array}{l}\text { SNP Microarray } \\
\text { (Affy } 100 \mathrm{~K} \text { ) }\end{array}$ & Neale et al. [50] & \\
\hline
\end{tabular}


Table 1: Continued.

\begin{tabular}{|c|c|c|c|c|c|c|}
\hline Deletion & Gain & $\begin{array}{c}\text { Ewing's sample } \\
\text { type }\end{array}$ & Frequency $(\%)$ & Technology & Study & Clinical significance \\
\hline 17 & & $\begin{array}{c}\text { ESFT and } \\
\text { Xenotransplant }\end{array}$ & $2 / 19(11 \%)$ & dPCR, FISH & $\begin{array}{l}\text { López-Guerrero } \\
\text { et al. [64] }\end{array}$ & \\
\hline $17 \mathrm{p}$ & & $\begin{array}{l}\text { ESFT } \\
\text { Cell line }\end{array}$ & $\begin{array}{r}9 / 62(15 \%) \\
4 / 8(50 \%)\end{array}$ & $\begin{array}{l}\mathrm{CGH} \\
\mathrm{CGH}\end{array}$ & $\begin{array}{l}\text { Ozaki et al. [48] } \\
\text { Shing et al. [55] }\end{array}$ & (i) Adverse overall survival \\
\hline \multirow[t]{3}{*}{$17 \mathrm{p} 13$} & & ESFT & $8 / 88(9 \%)$ & $\begin{array}{l}\text { Karyotyping } \\
\text { (G-Band) }\end{array}$ & Roberts et al. [49] & \\
\hline & $17 \mathrm{q} 21.31-\mathrm{q} 25.3$ & ESFT & $6 / 9(67 \%)$ & $\begin{array}{l}\text { SNP Microarray } \\
\text { (Affy } 100 \mathrm{~K})\end{array}$ & Neale et al. [50] & \\
\hline & 18 & ESFT & $6 / 68(9 \%)$ & $\mathrm{CGH}$ & $\begin{array}{l}\text { Brisset et al. [52]; } \\
\text { Ferreira et al. [56] }\end{array}$ & \\
\hline 19 & & ESFT & $4 / 25(16 \%)$ & $\mathrm{CGH}$ & Ferreira et al. [56] & \\
\hline $19 p$ & & ESFT & $7 / 62(11 \%)$ & $\mathrm{CGH}$ & Ozaki et al. [48] & \\
\hline \multirow[t]{7}{*}{$19 q$} & & ESFT & $11 / 62(18 \%)$ & $\mathrm{CGH}$ & Ozaki et al. [48] & \\
\hline & 20 & ESFT & $35 / 248(14 \%)$ & $\begin{array}{l}\text { Karyotyping and } \\
\text { CGH }\end{array}$ & $\begin{array}{l}\text { Brisset et al. [52]; } \\
\text { Ferreira et al. [56]; } \\
\text { Hattinger et al. [47]; } \\
\text { Roberts et al. [49] }\end{array}$ & $\begin{array}{l}\text { (i) Adverse event free survival } \\
\text { (ii) Adverse overall survival }\end{array}$ \\
\hline & $20 \mathrm{p}$ & ESFT & $11 / 62(18 \%)$ & $\mathrm{CGH}$ & Ozaki et al. [48] & (i) Adverse overall survival \\
\hline & $20 q$ & ESFT & $11 / 62(18 \%)$ & $\mathrm{CGH}$ & Ozaki et al. [48] & (i) Adverse overall survival \\
\hline & $\begin{array}{c}20 \mathrm{q} 11.23- \\
\mathrm{q} 13.33\end{array}$ & ESFT & $2 / 9(22 \%)$ & $\begin{array}{l}\text { SNP Microarray } \\
\text { (Affy } 100 \mathrm{~K})\end{array}$ & Neale et al. [50] & \\
\hline & $21 q 22.3$ & ESFT & $2 / 9(22 \%)$ & $\begin{array}{l}\text { SNP Microarray } \\
\text { (Affy } 100 \mathrm{~K})\end{array}$ & Neale et al. [50] & \\
\hline & $22 \mathrm{q} 11.21$ & ESFT & $2 / 9(22 \%)$ & $\begin{array}{l}\text { SNP Microarray } \\
(\text { Affy } 100 \mathrm{~K})\end{array}$ & Neale et al. [50] & \\
\hline $\mathrm{Y}$ & & Cell lines & $3 / 5(60 \%)$ & $\mathrm{CGH}$ & Shing et al. [55] & \\
\hline
\end{tabular}

* Modified from Toomey et al. Oncogene 2010. ESFT: Ewing's Sarcoma Family of Tumors, CGH: comparative genomic hybridization.

tumorigenesis and progression as part of $8 \mathrm{q}$ amplification that warrant future investigation based on their integrated outcome analysis $(P<.001$ and $P<.001$, resp. $)$ [53].

Trisomy 12 has been suggested to be linked to trisomy 8 . While one study found that every case with trisomy 12 was combined with trisomy 8 [51], others state the these trisomies are independent events [57]. The frequency of trisomy 12 occurring with trisomy 8 is higher than trisomy 12 alone, but both events have been shown to occur independently $[47,57]$. Copy number gains of 8 and/or 12 appear more frequently in local recurrences ( $83 \%$ of the time) compared to primary (47\%) and metastatic (42\%) lesions and are hypothesized to appear with increased frequency during tumor progression or after initial translocation [57]. Much like trisomy 8 , trisomy 12 has conflicting information regarding its clinical significance. However, many studies seem to suggest that trisomy 12 or focal amplifications on chromosome 12, are more important than those for chromosome 8. Trisomy 12 correlates to adverse-event-free survival $(P=.009)$ for individuals with localized disease [47]. Even though other reports of this trisomy show no statistical significance for overall survival $(P=.67)$ [54], evidence to the contrary links aberrations on $12 \mathrm{p}$ and $12 \mathrm{q}$ to reduced overall survival by univariate analysis $(P=.039$ and $P=.019$ ) [48]. In one set of Ewing's tumors, the smallest region of shared amplification on chromosome 12 contained two known oncogenes, ERBB3 and CDK4 [53]. These genes may be indicative of the importance of trisomy 12 and its role in tumorigenesis.

Amplifications and trisomies involving chromosomes 8 and 12 have conflicting findings regarding clinical and statistical significance. This is due to either the lack of statistical power in small sample sizes or the variable nature of the disease. In either case, neither trisomy was shown to be associated with improved prognostic outcome. This contrasts with descriptions of chromosome 2, which Brisset et al. reported to correlate with localized tumors rather than metastatic disease $(P=.02)$ [52]. However, again illustrating the variable nature of copy number studies in Ewing's sarcoma, Ozaki et al. described the association between gains of $2 \mathrm{q}$ and the reduction of overall survival $(P=.022)$ [48]. Perhaps the gain in chromosome 2 (specifically 2q) correlates with the more unusual localized tumors that also lead to relapse. Larger studies will be needed to clarify the importance of this amplification.

The gain of $1 \mathrm{q}$ is often reported with the loss of $16 \mathrm{q}$. This is the presumed artifact of an unbalanced translocation in Ewing's sarcoma, der(16)t $(1 ; 16)[47,48,51,52,54,55$, $66,68]$. Though it is difficult to separate the translocation's downstream effects from the resulting CNA's impact, specific 
clinical factors were linked to $16 \mathrm{q}$ loss such as age at diagnosis $\geq 15$ years and disseminated disease at diagnosis ( $P=.035$ and $P=.038$, resp.) [47]. The gain of $1 \mathrm{q}$ and the loss of $16 \mathrm{q}$ in combination with chromosome 12 gain also demonstrated an increased frequency of them occurring together $(P<.0001)$ [47]. The region of 1q gain, regardless of localized or disseminated disease, was determined to be significant for both adverse overall survival (localized disease $P=.002$; disseminated disease $P=.029)$ and event-free survival (localized disease $P=.018$; disseminated disease $P=.010)$ [47]. While 1q amplification showed no statistical significance in other studies, a high-level focal amplification was found at 1q21-q22 [51], two genes also reported in other sarcoma samples [69], SPRR3 with 5 copies and FLG with 4 copies were affected [51]. Other suspected candidates in 1q21-22 locus include $C A C Y$ and $C A P L$, both of which have been implicated in tumor progression and metastasis [51, 70]. 1q21-1q22 amplification has also been reported in other sarcomas $[69,71]$. This more focal 1q gain lacked statistical significance but still suggested association with adverse distant disease-free survival and overall survival [54].

Similar to the pairing of CNAs of 1q gain and 16q loss, combined losses of $16 \mathrm{q}$ and $17 \mathrm{p}$, resulting from another unbalanced translocation, have been described $[48,55]$.The loss of concomitant 16q and 17p has demonstrated lower overall survival $(P=.0012)[48] .17 p$ loss may have its major impact by encompassing the loss of the well-known tumor suppressor, TP53 $[47,64,72]$. In addition to TP53 deletion that is contained within 17p loss, mutation of TP53 has been reported to show an association with poor chemoresponse and overall survival in Ewing's sarcoma $(P=.03$ and $P<$ .001) [60].

Deletion of 9p21 encompassing CDKN2A (p16-INK4a) appeared in $10-73 \%$ of cases, including Ewing's sarcoma cell lines [50, 53, 59-62], with reported homozygous deletions in $8 \%$ [56] and $13 \%$ [60] of patient samples. This CDKN2A deletion was found to be a negative predictor of diseasespecific survival $(P=.001)$ : 7 patients with this deletion all died of disease before 36 months, 2 of which had metastases at diagnosis [63]. The combination of CDKN2A deletion and TP53 mutation was shown to be the most significant negative predictor of overall survival $(P<.001)$ [60]. Our own experience has demonstrated the $9 \mathrm{p} 21$ deletion to be much more common in cell lines (80\%) than clinical samples (5\%) (unpublished). Current studies validating the prevalence and prognostic significance of CDKN2A deletions and TP53 mutations in Ewing's sarcoma are underway through the Children's Oncology Group (COG).

3.2. Genomic Instability. Instability of cancer genomes leads to the accumulation of CNAs. Early findings showed no statistical link between total number of CNAs and worse outcome in Ewing's sarcoma [51]. However, later data indicated that unstable karyotypes with higher numbers of CNAs in Ewing's tumors may be a correlate with worse outcome $[53,55,56,58]$. CNAs totaling above three had worse prognosis in relation to event-free and overall survival $(P=.049$ and $P=.030)$ [53]. By clustering patients into two groups of genomic instability and stable genomes, prognostic significance was determined for overall survival via univariate and multivariate analysis $(P=.017$ and $P=$ .034) [56]. The group with increased genomic instability contained a reduced percentage of patients to reach complete remission, specifically $64 \%$ versus $100 \%$ [56].

3.3. Copy Number Mitochondrial Data. Mitochondrial DNA (mtDNA) copy number changes have been associated with increased risk of certain cancers. To date, breast cancer and renal cell carcinoma both have been associated with an increase in mtDNA and a decrease in mtDNA, respectively [73-75]. The displacement-(D-) loop of mitochondrial DNA (mtDNA), a noncoding region comprised of 1,124 base pairs, is more prone to mutation. These mutations, in conjunction with quantitative mtDNA changes, have been linked to Ewing's sarcoma $[75,76]$. The D-loop's increased mutation stems from its vulnerability to oxidative damage and reduced reparation capacity [75]. Decreased copy number of mtDNA is more often found in samples containing D-loop mutations $(P=.04)$ and could be a result of the transcriptional and replicating functions of the D-loop [75]. While both D-loop mutations and reduced content of mtDNA are at higher instance in Ewing's sarcoma, the greatest statistical significance was determined to be between low mtDNA copy number and tumor metastasis as all of the metastases in the study contained low numbers of mtDNA $(P=.029)$ [75].

3.4. Ewing's Sarcoma and Methylation Data. Of the vast array of oncogenic manipulations of gene expression achieved in malignant cells, not all arise from either random mutation or cytogenetic gains and losses resulting in CNAs. Methylation is an alternate method by which gene expression is changed in cancer cells [77]. Methylation is the addition of a methyl group, usually to the 5 position of the cytosine pyrimidine ring, most importantly on cytosine residues contiguous to guanine residues, in what are called $\mathrm{CpG}$ islands. CpG sequences, in general, are relatively scarce in the human genome, as spontaneous mutation of the $\mathrm{C}$ to a $\mathrm{T}$ residue is especially common in the methylated state. Most remaining $\mathrm{CpGs}$ in the human genome are in the $5^{\prime}$ regulatory and promoter sequences of genes.

Methylation of these promoter CpGs provides a cellheritable means by which expression can be regulated. When a new zygote is formed, the cell is extensively demethylated. As cell division proceeds and eventually differentiation, methylation also proceeds, silencing certain genes no longer necessary along the cell's prescribed differentiation course. Methylation of promoter $\mathrm{CpG}$ islands affects transcription of the nearby gene via physical interruption of the binding of transcription factors and by encouraging binding of methyl-CpG-binding domain proteins. This recruits histone deacetylase and other chromatin-remodeling proteins, resulting in tight chromatin packaging of the locus and exclusion of transcriptional machinery. This silenced state of the gene is then passed on to daughter cells. Normal methylation is an important developmental program by which dangerous genes, such as viral sequences integrated into the human genome over generations, and early developmental genes can be silenced when necessary. 
Cancer cells can have a variety of problems with methylation. Some powerful oncogenes from integrated viruses and developmental genes that engender a highly proliferative state are often demethylated in cancers, resulting in their aberrant and deleterious expression. In addition, the promoters of many tumor suppressor genes are over-methylated resulting in their silencing. Obviously, genomic sequencing or usual hybridization techniques will not detect promoter methylation or demethylation. These powerful epigenetic modifications of genes are only noted when specifically sought. While dedicated efforts are underway to understand methylation in many cancer types, such large scale efforts are lacking for the Ewing's sarcoma family of tumors. In fact, the relative absence of wild karyotype anomalies and rampant mutations argues that epigenetic modifications such as methylation may be a prominent mechanism of disease in sarcomas bearing balanced translocations such as Ewing's sarcoma. While methylation and epigenetics have only received limited attention in the literature thus far, they seem likely to be important genetic mechanisms for Ewing's sarcomagenesis and progression.

Two studies have assessed genetic alterations in the $9 \mathrm{p} 21$ locus in Ewing's sarcoma [64, 78]. One identified 4 tumors with homozygous deletion and 2 with promoter hypermethylation of CDKN2A among 26 tumors in total [64]. Two tumors had codeletion of CDKN2B (p15-INK4b) and 3 promoter hypermethylation of p15 [64]. The second study found 1 methylated, 1 point-mutated, and 2 homozygous deleted CDKN2A among 24 tumors, as well as 2 methylated and 2 homozygous deleted CDKN2B [78].

Another gene studied with respect to promoter methylation in Ewing's sarcoma is RASSF1A. One study interrogated RASSF1A along with p16, MGMT, GSTP1, APC, DAPK, RAR $\beta, C D H 1$, and $C D H 13$ and found only MGMT and CDH1 promoters methylated in 1 of $8(12.5 \%)$ Ewing's sarcoma tumor samples [79]. Failure to detect CDKN2A promoter methylation in this study can be reconciled with the results of the larger studies described above based simply on insufficient sample size. With respect to RASSF1A, these results are more difficult to reconcile with the high frequency of RASSF1A methylation in a previously published report [80]; Avigad et al. identified 21 of $31(68 \%)$ patient samples and 1 of $4(25 \%)$ cell lines with hemizygous promoter methylation and 2 of $4(50 \%)$ cell lines with homozygous promoter methylation. This larger study also correlated reduced RASSF1A expression with promoter methylation in 12 tumors checked. Further, they demonstrated reexpression of RASSF1A in the 2 homozygous methylated cell lines, upon in vitro application of 5-aza-2' deoxycytidine, a powerful demethylating agent.

Two studies have corroborated each other in identifying 1 of $4(25 \%)$ and 9 of 41 (22\%) Ewing's cell lines with reduced caspase 8 expression, secondary to promoter methylation $[81,82]$. The larger of these studies went further to confirm this reduced or lost caspase 8 expression by promoter methylation as the mechanism by which the 9 cell lines evaded TRAIL-induced apoptosis [82]. They confirmed the absence of deletions in the caspase 8 gene, as well as the reexpression of caspase 8 upon 5 -aza- $2^{\prime}$ deoxycytidine administration. Reexpression restored TRAIL and cytotoxic chemotherapy-induced apoptosis in these cell lines. They further checked 20 primary Ewing's sarcoma tumor samples, where they identified the predominance of the methylated caspase 8 promoter in 13 cases.

Finally, 5-aza-2' deoxycytidine-driven demethylation has been tested as a means of disrupting the transformed phenotype of Ewing's sarcoma cell lines [83]. Using a clonogenic assay, demethylation alone dropped clonogenicity by 20 percent. Synergistic with a panel of histone deacetylase inhibitors, effects of 80 to 90 percent disruption of clonogenicity were detected, in addition to the reexpression of tumor suppressors such as E-cadherin and TSLC1.

\section{Conclusions}

In this paper, we focused primarily on copy number and methylation data. We also acknowledge the importance of other molecular changes potentially at work in Ewing's sarcomagenesis such as pleiotropic effects of the chromosomal translocation beyond creation of the specific fusion oncogene, somatic mutations in yet uninterrogated tumor suppressors, increased expression of oncogenes or oncogenic microRNAs, and other epigenetic mechanisms of expression regulation such as histone and chromatin packaging that could not be covered within the scope of this review. CNAs and methylation changes in Ewing's sarcoma, along with some of these yet unexplored genetic and epigenetic perturbations may be essential to Ewing's tumorigenesis as evidence suggests that the EWS-FLI1 translocation is necessary but not sufficient for Ewing's transformation in vitro [31]; CNAs and methylation changes may form some of the necessary second hits required for Ewing's sarcoma to develop. The complex cooperative relationships of these many molecular mechanisms of expression alteration have not been fully explored, and a full-system biology approach may prove to be informative in the field of Ewing's sarcoma. As explored in this review, isolated combinations of chromosomal gains and deletions already have begun to be described. Unfortunately, the results of the limited copy number studies are rarely in agreement likely due to poor statistical power in each small sample studied. In many instances, statistical significance cannot be determined, but trends still suggest that these CNAs have prognostic impact or contribute to genomic instability associated with worse outcome.

The investigation of copy number in Ewing's sarcoma will continue to advance given the rapid acceleration of high-resolution genomic technology to interrogate clinical samples, including archived FFPE specimens. Discovery of specific genes (rather than larger chromosomal cytobands) associated with tumor development and outcome will extend rapidly as the coverage in new SNP microarray platforms continues to become more dense and whole genome sequencing becomes more affordable. Novel and recurrent CNAs have been reported to cover nearly the entire genome. The main copy number recurrences in Ewing's sarcoma included trisomies 8 and 12, along with 1q amplification. These findings were consistent throughout the majority of studies, despite the inability of many studies to find statistical 
significance related to treatment response, prognosis, outcome, or tendency to relapse. Although several recurring regions, such as, $16 \mathrm{q}$ deletions, have been repeatedly shown in different copy number studies to be associated with worse outcomes, these findings still await validation and incorporation into clinical trials.

For methylation as a mechanism of sarcomagenesis, two prominent tumor suppressor loci, CDKN2A and RASSF1A, as well as one important apoptosis activator, caspase 8, have been implicated. Further, functional assays have shown the reversibility of these expression repressions by the application of demethylating agents. For these methylationassociated genetic perturbations, therapeutic implications are very direct because the clinical drugs affecting methylation status and downstream histone deacetylation are already available for patient use. We expect that researchers have only scratched the surface of the Ewing's methylome. With the knowledge of demethylated oncogenes and other methylation-silenced tumor suppressors, the mechanisms leading to further CNAs and increased genomic instability with tumor proliferation may be elucidated. The continued investigation of copy number and methylation in Ewing's sarcoma will lead to a better understanding of tumorigenesis, more accurate risk stratification and hopefully new targets for developmental therapeutics. As genomic technology continues to improve, CNA and methylation changes detected in clinical samples can be rapidly incorporated into patient care to improve the outcome in Ewing's sarcoma.

\section{Conflict of Interests}

The authors declare no conflict of interests.

\section{Acknowledgments}

K. B. Jones is supported by K08CA138764 from the National Cancer Institute. His pertinent research is also supported by the Paul Nabil Bustany Fund for Synovial Sarcoma Research and the Huntsman Cancer Institute Nuclear Control Program. J. D. Schiffman is supported by a Sarcoma Alliance for Research Collaboration (SARC) Career Development Award.

\section{References}

[1] L. Granowetter, R. Womer, M. Devidas et al., "Doseintensified compared with standard chemotherapy for nonmetastatic ewing sarcoma family of tumors: a children's oncology group study," Journal of Clinical Oncology, vol. 27, no. 15, pp. 2536-2541, 2009.

[2] H. E. Grier, M. D. Krailo, N. J. Tarbell et al., "Addition of ifosfamide and etoposide to standard chemotherapy for Ewing's sarcoma and primitive neuroectodermal tumor of bone," New England Journal of Medicine, vol. 348, no. 8, pp. 694-701, 2003.

[3] L. M. Barker, T. W. Pendergrass, J. E. Sanders, and D. S. Hawkins, "Survival after recurrence of Ewing's sarcoma family of tumors," Journal of Clinical Oncology, vol. 23, no. 19, pp. 4354-4362, 2005.

[4] C. Rodriguez-Galindo, C. A. Billups, L. E. Kun et al., "Survival after recurrence of ewing tumors: the St. Jude children's research hospital experience, 1979-1999," Cancer, vol. 94, no. 2, pp. 561-569, 2002.

[5] A. G. Shankar, S. Ashley, A. W. Craft, and C. R. Pinkerton, "Outcome after relapse in an unselected cohort of children and adolescents with Ewing sarcoma," Medical and Pediatric Oncology, vol. 40, no. 3, pp. 141-147, 2003.

[6] S. G. DuBois, M. D. Krailo, S. L. Lessnick et al., "Phase II study of intermediate-dose cytarabine in patients with relapsed or refractory ewing sarcoma: a report from the children's oncology group," Pediatric Blood and Cancer, vol. 52, no. 3, pp. 324-327, 2009.

[7] J. S. Miser, M. D. Krailo, N. J. Tarbell et al., "Treatment of metastatic Ewing's sarcoma or primitive neuroectodermal tumor of bone: evaluation of combination ifosfamide and etoposide-a children's cancer group and pediatric oncology group study," Journal of Clinical Oncology, vol. 22, no. 14, pp. 2873-2876, 2004.

[8] S. A. Burchill, "Ewing's sarcoma: diagnostic, prognostic, and therapeutic implications of molecular abnormalities," Journal of Clinical Pathology, vol. 56, no. 2, pp. 96-102, 2003.

[9] C. R. Walkley, R. Qudsi, V. G. Sankaran et al., "Conditional mouse osteosarcoma, dependent on p53 loss and potentiated by loss of Rb, mimics the human disease," Genes and Development, vol. 22, no. 12, pp. 1662-1676, 2008.

[10] N. Riggi, L. Cironi, P. Provero et al., "Development of Ewing's sarcoma from primary bone marrow-derived mesenchymal progenitor cells," Cancer Research, vol. 65, no. 24, pp. 1145911468, 2005.

[11] N. Riggi, M. L. Suvà, D. Suvà et al., "EWS-FLI-1 expression triggers a ewing's sarcoma initiation program in primary human mesenchymal stem cells," Cancer Research, vol. 68, no. 7, pp. 2176-2185, 2008.

[12] F. Tirode, K. Laud-Duval, A. Prieur, B. Delorme, P. Charbord, and O. Delattre, "Mesenchymal stem cell features of Ewing tumors," Cancer Cell, vol. 11, no. 5, pp. 421-429, 2007.

[13] F. Baliko, T. Bright, R. Poon, B. Cohen, S. E. Egan, and B. A. Alman, "Inhibition of notch signaling induces neural differentiation in Ewing sarcoma," American Journal of Pathology, vol. 170, no. 5, pp. 1686-1694, 2007.

[14] A. O. Cavazzana, J. S. Miser, J. Jefferson, and T. J. Triche, "Experimental evidence for a neural origin of Ewing's sarcoma of bone," American Journal of Pathology, vol. 127, no. 3, pp. 507-518, 1987.

[15] A. Franchi, G. Pasquinelli, G. Cenacchi et al., "Immunohistochemical and ultrastructural investigation of neural differentiation in Ewing sarcoma/PNET of bone and soft tissues," Ultrastructural Pathology, vol. 25, no. 3, pp. 219-225, 2001.

[16] M. Lipinski, K. Braham, and I. Philip, "Neuroectodermassociated antigens on Ewing's sarcoma cell lines," Cancer Research, vol. 47, no. 1, pp. 183-187, 1987.

[17] M. S. Staege, C. Hutter, I. Neumann et al., "DNA microarrays reveal relationship of Ewing family tumors to both endothelial and fetal neural crest-derived cells and define novel targets," Cancer Research, vol. 64, no. 22, pp. 8213-8221, 2004.

[18] O. Delattre, J. Zucman, B. Plougastel et al., "Gene fusion with an ETS DNA-binding domain caused by chromosome translocation in human tumours," Nature, vol. 359, no. 6391, pp. 162-165, 1992.

[19] I. S. Jeon, J. N. Davis, B. S. Braun et al., "A variant Ewing's sarcoma translocation $(7 ; 22)$ fuses the EWS gene to the ETS gene ETV1," Oncogene, vol. 10, no. 6, pp. 1229-1234, 1995.

[20] M. Peter, J. Couturier, H. Pacquement et al., "A new member of the ETS family fused to EWS in Ewing tumors," Oncogene, vol. 14, no. 10, pp. 1159-1164, 1997. 
[21] P. H. B. Sorensen, S. L. Lessnick, D. Lopez-Terrada, X. F. Liu, T. J. Triche, and C. T. Denny, "A second Ewing's sarcoma translocation, $t(21 ; 22)$, fuses the EWS gene to another ETSfamily transcription factor, ERG," Nature Genetics, vol. 6, no. 2, pp. 146-151, 1994.

[22] C. Turc-Carel, A. Aurias, F. Mugneret et al., "Chromosomes in Ewing's sarcoma. I. An evaluation of 85 cases and remarkable consistency of $\mathrm{t}(11 ; 22)(\mathrm{q} 24 ; \mathrm{q} 12)$," Cancer Genetics and Cytogenetics, vol. 32, no. 2, pp. 229-238, 1988.

[23] S. L. Lessnick, B. S. Braun, C. T. Denny, and W. A. May, "Multiple domains mediate transformation by the Ewing's sarcoma EWS/FLI-1 fusion gene," Oncogene, vol. 10, no. 3, pp. 423-431, 1995.

[24] B. S. Braun, R. Frieden, S. L. Lessnick, W. A. May, and C. T. Denny, "Identification of target genes for the Ewing's sarcoma EWS/FLI fusion protein by representational difference analysis," Molecular and Cellular Biology, vol. 15, no. 8, pp. 4623 4630, 1995.

[25] M. Kinsey, R. Smith, and S. L. Lessnick, "NR0B1 is required for the oncogenic phenotype mediated by EWS/FLI in Ewing's sarcoma," Molecular Cancer Research, vol. 4, no. 11, pp. 851$859,2006$.

[26] W. Luo, K. Gangwal, S. Sankar, K. M. Boucher, D. Thomas, and S. L. Lessnick, "GSTM4 is a microsatellite-containing EWS/FLI target involved in Ewing's sarcoma oncogenesis and therapeutic resistance," Oncogene, vol. 28, no. 46, pp. 41264132, 2009.

[27] L. A. Owen and S. L. Lessnick, "Identification of target genes in their native cellular context: an analysis of EWS/FLI in Ewing's sarcoma," Cell Cycle, vol. 5, no. 18, pp. 2049-2053, 2006.

[28] G. Potikyan, R. O. V. Savene, J. M. Gaulden et al., "EWS/FLI1 regulates tumor angiogenesis in Ewing's sarcoma via suppression of thrombospondins," Cancer Research, vol. 67, no. 14, pp. 6675-6684, 2007.

[29] R. Smith, L. A. Owen, D. J. Trem et al., "Expression profiling of EWS/FLI identifies NKX2.2 as a critical target gene in Ewing's sarcoma," Cancer Cell, vol. 9, no. 5, pp. 405-416, 2006.

[30] J. P. Zwerner and W. A. May, "PDGC-C is an EWS/FLI induced transforming growth factor in Ewing family tumors," Oncogene, vol. 20, no. 5, pp. 626-633, 2001.

[31] E. C. Toomey, J. D. Schiffman, and S. L. Lessnick, "Recent advances in the molecular pathogenesis of Ewing's sarcoma," Oncogene, vol. 29, no. 32, pp. 4504-4516, 2010.

[32] T. Watanabe, T. T. Wu, P. J. Catalano et al., "Molecular predictors of survival after adjuvant chemotherapy for colon cancer," New England Journal of Medicine, vol. 344, no. 16, pp. 1196-1206, 2001.

[33] B. H. Kushner and N. K. V. Cheung, "Neuroblastoma-from genetic profiles to clinical challenge," New England Journal of Medicine, vol. 353, no. 21, pp. 2215-2217, 2005.

[34] L. Mariani, G. Deiana, E. Vassella et al., "Loss of heterozygosity 1 p36 and $19 q 13$ is a prognostic factor for overall survival in patients with diffuse WHO grade 2 gliomas treated without chemotherapy," Journal of Clinical Oncology, vol. 24, no. 29, pp. 4758-4763, 2006.

[35] C. Oudin, F. Bonnetain, R. Boidot et al., "Patterns of loss of heterozygosity in breast carcinoma during neoadjuvant chemotherapy," International Journal of Oncology, vol. 30, no. 5, pp. 1145-1151, 2007.

[36] C. H. Pui and W. E. Evans, "Treatment of acute lymphoblastic leukemia," New England Journal of Medicine, vol. 354, no. 2, pp. 166-178, 2006.
[37] J. A. E. Irving, L. Bloodworth, N. P. Bown, M. C. Case, L. A. Hogarth, and A. G. Hall, "Loss of heterozygosity in childhood acute lymphoblastic leukemia detected by genomewide microarray single nucleotide polymorphism analysis," Cancer Research, vol. 65, no. 8, pp. 3053-3058, 2005.

[38] C. G. Mullighan, S. Goorha, I. Radtke et al., "Genomewide analysis of genetic alterations in acute lymphoblastic leukaemia," Nature, vol. 446, no. 7137, pp. 758-764, 2007.

[39] C. G. Mullighan, C. B. Miller, I. Radtke et al., "BCR-ABL1 lymphoblastic leukaemia is characterized by the deletion of Ikaros," Nature, vol. 453, no. 7191, pp. 110-114, 2008.

[40] N. Kawamata, S. Ogawa, M. Zimmermann et al., "Molecular allelokaryotyping of pediatric acute lymphoblastic leukemias by high-resolution single nucleotide polymorphism oligonucleotide genomic microarray," Blood, vol. 111, no. 2, pp. 776784, 2008.

[41] R. P. Kuiper, E. F. P. M. Schoenmakers, S. V. van Reijmersdal et al., "High-resolution genomic profiling of childhood ALL reveals novel recurrent genetic lesions affecting pathways involved in lymphocyte differentiation and cell cycle progression," Leukemia, vol. 21, no. 6, pp. 1258-1266, 2007.

[42] J. D. Schiffman, Y. Wang, L. A. McPherson et al., "Molecular inversion probes reveal patterns of 9p21 deletion and copy number aberrations in childhood leukemia," Cancer Genetics and Cytogenetics, vol. 193, no. 1, pp. 9-18, 2009.

[43] C. G. Mullighan, L. A. Phillips, X. Su et al., "Genomic analysis of the clonal origins of relapsed acute lymphoblastic leukemia," Science, vol. 322, no. 5906, pp. 1377-1380, 2008.

[44] J. J. Yang, D. Bhojwani, W. Yang et al., "Genome-wide copy number profiling reveals molecular evolution from diagnosis to relapse in childhood acute lymphoblastic leukemia," Blood, vol. 112, no. 10, pp. 4178-4183, 2008.

[45] J. D. Schiffman, J. G. Hodgson, S. R. VandenBerg et al., "Oncogenic BRAF mutation with CDKN2A inactivation is characteristic of a subset of pediatric malignant astrocytomas," Cancer Research, vol. 70, no. 2, pp. 512-519, 2010.

[46] J. P. Robinson, M. W. Vanbrocklin, A. R. Guilbeault, D. L. Signorelli, S. Brandner, and S. L. Holmen, "Activated BRAF induces gliomas in mice when combined with Ink4a/Arf loss or Akt activation," Oncogene, vol. 29, no. 3, pp. 335-344, 2010.

[47] C. M. Hattinger, U. Pötschger, M. Tarkkanen et al., "Prognostic impact of chromosomal aberrations in Ewing tumours," British Journal of Cancer, vol. 86, no. 11, pp. 1763-1769, 2002.

[48] T. Ozaki, M. Paulussen, C. Poremba et al., "Genetic imbalances revealed by comparative genomic hybridization in Ewing tumors," Genes Chromosomes and Cancer, vol. 32, no. 2, pp. 164-171, 2001.

[49] P. Roberts, S. A. Burchill, S. Brownhill et al., "Ploidy and karyotype complexity are powerful prognostic indicators in the Ewing's sarcoma family of tumors: a study by the United Kingdom cancer cytogenetics and the children's cancer and leukaemia group," Genes Chromosomes and Cancer, vol. 47, no. 3, pp. 207-220, 2008.

[50] G. Neale, X. Su, C. L. Morton et al., "Molecular characterization of the pediatric preclinical testing panel," Clinical Cancer Research, vol. 14, no. 14, pp. 4572-4583, 2008.

[51] G. Armengol, M. Tarkkanen, M. Virolainen et al., "Recurrent gains of $1 \mathrm{q}, 8$ and 12 in the Ewing family of tumours by comparative genomic hybridization," British Journal of Cancer, vol. 75, no. 10, pp. 1403-1409, 1997.

[52] S. Brisset, G. Schleiermacher, M. Peter et al., "CGH analysis of secondary genetic changes in Ewing tumors: correlation with metastatic disease in a series of 43 cases," Cancer Genetics and Cytogenetics, vol. 130, no. 1, pp. 57-61, 2001. 
[53] S. Savola, A. Klami, A. Tripathi et al., "Combined use of expression and CGH arrays pinpoints novel candidate genes in Ewing sarcoma family of tumors," BMC Cancer, vol. 9, article 17, 2009.

[54] M. Tarkkanen, S. Kiuru-Kuhlefelt, C. Blomqvist et al., "Clinical correlations of genetic changes by comparative genomic hybridization in Ewing sarcoma and related tumors," Cancer Genetics and Cytogenetics, vol. 114, no. 1, pp. 35-41, 1999.

[55] D. C. Shing, C. A. Morley-Jacob, I. Roberts, E. Nacheva, and N. Coleman, "Ewing's tumour: novel recurrent chromosomal abnormalities demonstrated by molecular cytogenetic analysis of seven cell lines and one primary culture," Cytogenetic and Genome Research, vol. 97, no. 1-2, pp. 20-27, 2002.

[56] B. I. Ferreira, J. Alonso, J. Carrillo et al., "Array CGH and gene-expression profiling reveals distinct genomic instability patterns associated with DNA repair and cell-cycle checkpoint pathways in Ewing's sarcoma," Oncogene, vol. 27, no. 14, pp. 2084-2090, 2008.

[57] D. Maurici, A. Perez-Atayde, H. E. Grier, N. Baldini, M. Serra, and J. A. Fletcher, "Frequency and implications of chromosome 8 and 12 gains in Ewing sarcoma," Cancer Genetics and Cytogenetics, vol. 100, no. 2, pp. 106-110, 1998.

[58] M. Zielenska, Z. M. Zhang, K. Ng et al., "Acquisition of secondary structural chromosomal changes in pediatric Ewing sarcoma is a probable prognostic factor for tumor response and clinical outcome," Cancer, vol. 91, no. 11, pp. 2156-2164, 2001.

[59] S. C. Brownhill, C. Taylor, and S. A. Burchill, "Chromosome 9p21 gene copy number and prognostic significance of p16 in ESFT," British Journal of Cancer, vol. 96, no. 12, pp. 1914-1923, 2007.

[60] H. Y. Huang, P. B. Illei, Z. Zhao et al., "Ewing sarcomas with p53 mutation or p16/p14ARF homozygous deletion: a highly lethal subset associated with poor chemoresponse," Journal of Clinical Oncology, vol. 23, no. 3, pp. 548-558, 2005.

[61] H. Kovar, G. Jug, D. N. T. Aryee et al., "Among genes involved in the $\mathrm{RB}$ dependent cell cycle regulatory cascade, the p16 tumor suppressor gene is frequently lost in the Ewing family of tumors," Oncogene, vol. 15, no. 18, pp. 2225-2232, 1997.

[62] S. Savola, F. Nardi, K. Scotlandi, P. Picci, and S. Knuutila, "Microdeletions in 9p21.3 induce false negative results in CDKN2A FISH analysis of Ewing sarcoma," Cytogenetic and Genome Research, vol. 119, no. 1-2, pp. 21-26, 2007.

[63] G. Wei, C. R. Antonescu, E. De Alava et al., "Prognostic impact of INK4A deletion in Ewing sarcoma," Cancer, vol. 89, no. 4, pp. 793-799, 2000.

[64] J. A. López-Guerrero, A. Pellín, R. Noguera, C. Carda, and A. Llombart-Bosch, "Molecular analysis of the 9p21 locus and p53 genes in Ewing family tumors," Laboratory Investigation, vol. 81, no. 6, pp. 803-814, 2001.

[65] Y. Wang, V. E. Carlton, G. Karlin-Neumann et al., "High quality copy number and genotype data from FFPE samples using Molecular Inversion Probe (MIP) microarrays," BMC Medical Genomics, vol. 2, article 8, 2009.

[66] F. Mugneret, S. Lizard, A. Aurias, and C. Turc-Carel, "Chromosomes in Ewing's sarcoma. II. Nonrandom additional changes, trisomy 8 and $\operatorname{der}(16) \mathrm{t}(1 ; 16)$, , Cancer Genetics and Cytogenetics, vol. 32, no. 2, pp. 239-245, 1988.

[67] S. Selvarajah, M. Yoshimoto, M. Prasad et al., "Characterization of trisomy 8 in pediatric undifferentiated sarcomas using advanced molecular cytogenetic techniques," Cancer Genetics and Cytogenetics, vol. 174, no. 1, pp. 35-41, 2007.

[68] E. C. Douglass, S. T. Rowe, M. Valentine, D. Parham, W. H. Meyer, and E. I. Thompson, "A second nonrandom translocation, der(16)t $(1 ; 16)(\mathrm{q} 21 ; \mathrm{q} 13)$, in Ewing sarcoma and peripheral neuroectodermal tumor," Cytogenetics and Cell Genetics, vol. 53, no. 2-3, pp. 87-90, 1990.

[69] A. Forus, J. M. Berner, L. A. Meza-Zepeda et al., "Molecular characterization of a novel amplicon at 1q21-q22 frequently observed in human sarcomas," British Journal of Cancer, vol. 78, no. 4, pp. 495-503, 1998.

[70] D. Engelkamp, B. W. Schafer, M. G. Mattei, P. Erne, and C. W. Heizmann, "Six S100 genes are clustered on human chromosome 1q21: identification of two genes coding for the two previously unreported calcium-binding proteins S100D and S100E," Proceedings of the National Academy of Sciences of the United States of America, vol. 90, no. 14, pp. 6547-6551, 1993.

[71] S. Knuutila, G. Armengol, A. M. Björkqvist et al., "Comparative genomic hybridization study on pooled DNAs from tumors of one clinical-pathological entity," Cancer Genetics and Cytogenetics, vol. 100, no. 1, pp. 25-30, 1998.

[72] E. De Alava, C. R. Antonescu, A. Panizo et al., "Prognostic impact of P53 status in Ewing sarcoma," Cancer, vol. 89, no. 4, pp. 783-792, 2000.

[73] J. Shen, M. Platek, A. Mahasneh, C. B. Ambrosone, and H. Zhao, "Mitochondrial copy number and risk of breast cancer: a pilot study," Mitochondrion, vol. 10, no. 1, pp. 62-68, 2010.

[74] J. Xing, M. Chen, C. G. Wood et al., "Mitochondrial DNA content: its genetic heritability and association with renal cell carcinoma," Journal of the National Cancer Institute, vol. 100, no. 15, pp. 1104-1112, 2008.

[75] M. Yu, Y. Wan, and Q. Zou, "Decreased copy number of mitochondrial DNA in ewing's sarcoma," Clinica Chimica Acta, vol. 411, no. 9-10, pp. 679-683, 2010.

[76] M. Yu, Y. Wan, Q. Zou, and Y. Xi, "High frequency of mitochondrial DNA D-loop mutations in Ewing's sarcoma," Biochemical and Biophysical Research Communications, vol. 390, no. 3, pp. 447-450, 2009.

[77] P. A. Jones and S. B. Baylin, "The fundamental role of epigenetic events in cancer," Nature Reviews Genetics, vol. 3, no. 6, pp. 415-428, 2002.

[78] T. Tsuchiya, K. I. Sekine, S. I. Hinohara, T. Namiki, T. Nobori, and Y. Kaneko, "Analysis of the p16INK4, p14ARF, p15, TP53, and MDM2 genes and their prognostic implications in osteosarcoma and Ewing sarcoma," Cancer Genetics and Cytogenetics, vol. 120, no. 2, pp. 91-98, 2000.

[79] K. Harada, S. Toyooka, A. Maitra et al., "Aberrant promoter methylation and silencing of the RASSF1A gene in pediatric tumors and cell lines," Oncogene, vol. 21, no. 27, pp. 43454349, 2002.

[80] S. Avigad, S. Shukla, I. Naumov et al., "Aberrant methylation and reduced expression of RASSF1A in Ewing sarcoma," Pediatric Blood and Cancer, vol. 53, no. 6, pp. 1023-1028, 2009.

[81] M. Ebinger, L. Senf, O. Wachowski, and W. Scheurlen, "Promoter methylation pattern of caspase-8, P16INK4A, MGMT, TIMP-3, and E-cadherin in medulloblastoma," Pathology and Oncology Research, vol. 10, no. 1, pp. 17-21, 2004.

[82] S. Fulda, M. U. Küfer, E. Meyer, F. Van Valen, B. DockhornDworniczak, and K. M. Debatin, "Sensitization for death receptor- or drug-induced apoptosis by re-expression of caspase- 8 through demethylation or gene transfer," Oncogene, vol. 20, no. 41, pp. 5865-5877, 2001.

[83] A. Hurtubise, M. L. Bernstein, and R. L. Momparler, "Preclinical evaluation of the antineoplastic action of 5-aza-2 deoxycytidine and different histone deacetylase inhibitors on human Ewing's sarcoma cells," Cancer Cell International, vol. 8, article 16, 2008. 


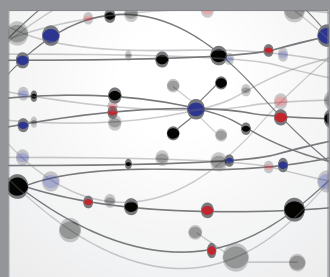

The Scientific World Journal
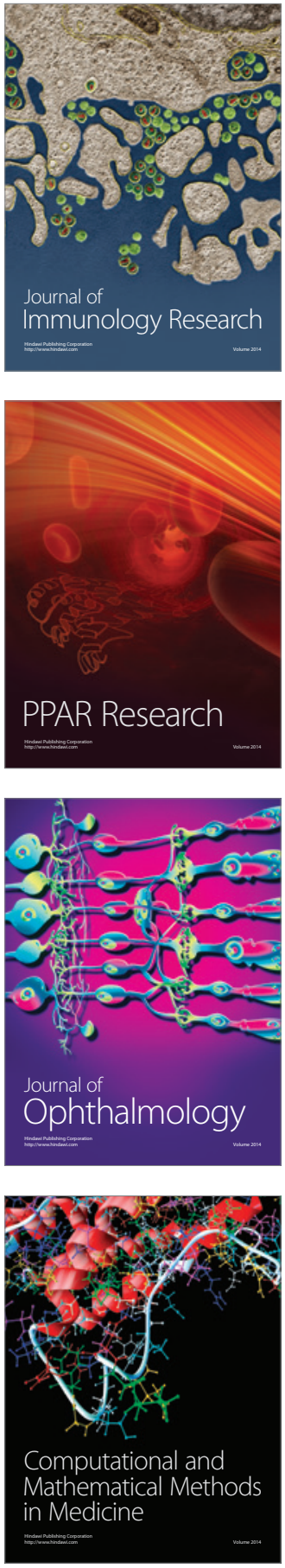

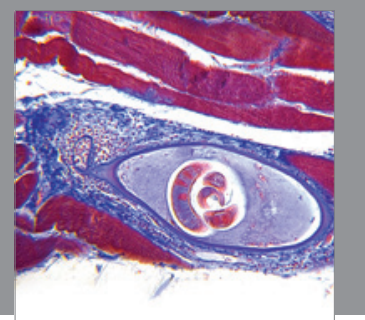

Gastroenterology

Research and Practice
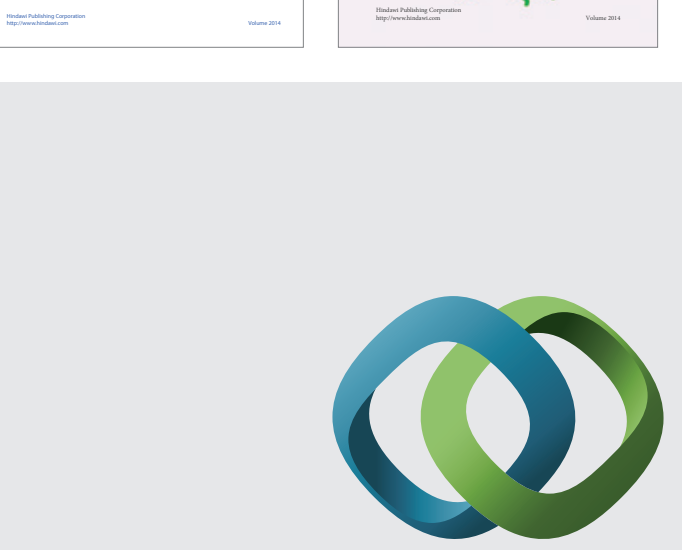

\section{Hindawi}

Submit your manuscripts at

http://www.hindawi.com
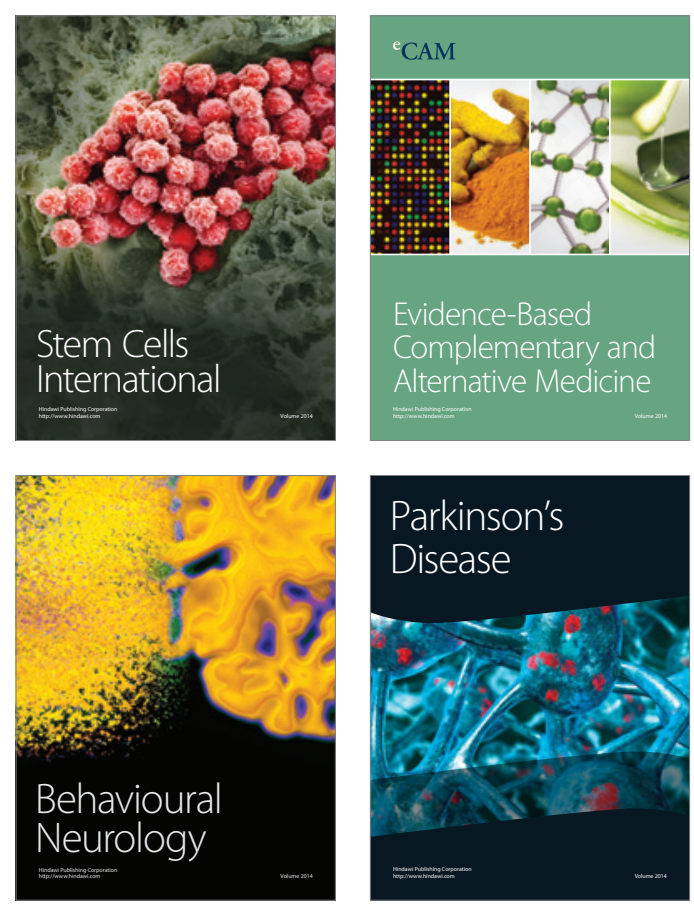

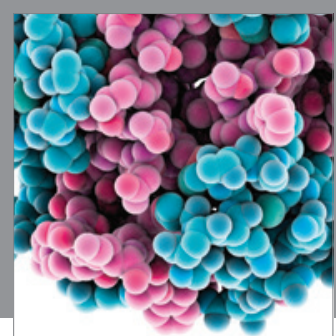

Journal of
Diabetes Research

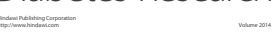

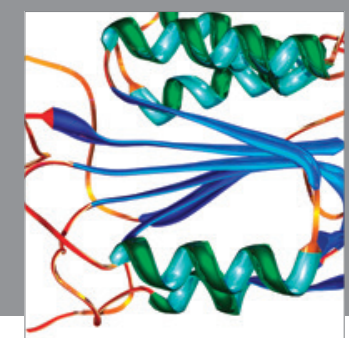

Disease Markers
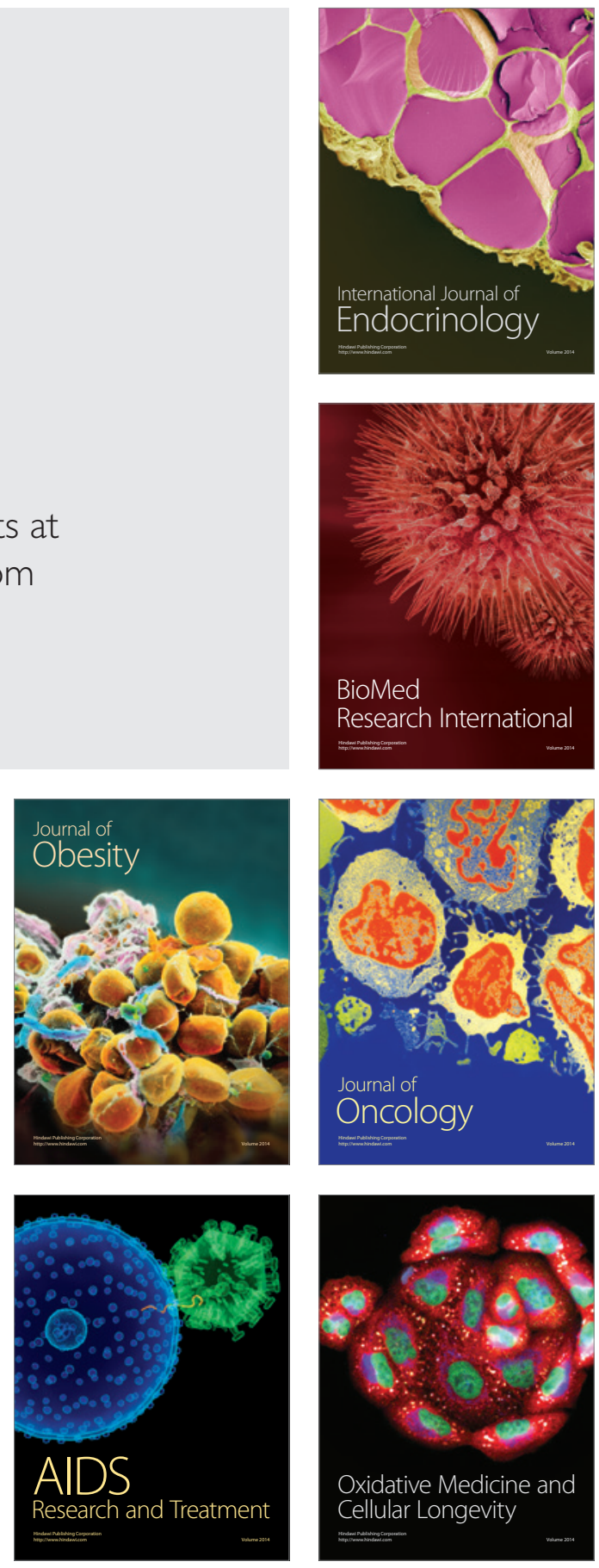